\title{
Analisis Formasi Pegawai Negeri Sipil Lingkup Pemerintah Daerah Kabupaten Buton Utara
}

\author{
Mohammad Rahmansyah ${ }^{1}$; Jopang ${ }^{2}$; Yaya Mulyana ${ }^{3}$ \\ ${ }^{1}$ Mahasiswa Magister Administrasi Publik, Universitas Terbuka, \\ rahmansyah1982.saraea@gmail.com \\ ${ }^{2}$ Fakultas Ilmu Sosial dan Ilmu Politik, Universitas Halu Oleo, jopang@uho.ac.id \\ ${ }^{3}$ Fakultas Ilmu Sosial dan Ilmu Politik, Universitas Pasundan, mulyana- \\ yaya@yahoo.com
}

\begin{abstract}
Abstrak
Secara ideal dalam menetapkan formasi PNS berbasis kebutuhan ditinjau dari jenis, sifat dan beban kerja pada setiap unit instansi pemerintah. Kebijakan pemerintah dalam menetapkan formasi PNS senantiasa berdasarkan pertimbangan anggaran yang tercantum dalam APBD Kabupaten/Kota masing-masing. Penelitian ini dilakukan untuk mengetahui analisis formasi dalam Pengadaan PNS Lingkup Pemda Kabupaten Buton Utara. Penelitian ini mernggunakan pendekatan kualitatif, dengan fokus penelitian pada formasi PNS lingkup Pemerintah Kabupaten Buton Utara. Informan dalam penelitian ini berjumlah 6 orang yang terdiri atas 3 orang pejabat di BKPSDM Buton Utara, 1 orang CPNS dan 2 orang tokoh masyarakat yang dipilih dengan mengunakan teknik Purposive sampling. Data dikumpulkan dengan metode wawancara, observasi dan studi dokumen. Data yang dikumpulkan selanjutnya dianalisis secara deskriptif, dengan tahapan pengumpulan data, pengolahan data, reduksi data dan penarikan kesimpulan. Data yang telah dianalisis selanjutnya dilakukan triangulasi untuk memperoleh gambaran tentang analisis formasi pengadaan PNS di Kabupaten Buton Utara. Hasil penelitian menunjukkan Analisis formasi Dalam Pengadaan PNS Lingkup Pemda Kabupaten Buton Utara belum sepenuhnya menggunakan indikator peta jabatan, jumlah pegawai yang pensiun setiap tahun dan rasio jumlah penduduk dengan PNS. Ketiga indikator tersebut tidak dilakukan analisis secara mendalam sehingga formasi pengadaan PNS tidak sesuai dengan kebutuhan rill jabatan yang ada di Kabupaten Buton Utara. Namun demikian Pemerintah Kabupaten Buton Utara telah menyediakan anggaran melalui APBD Kabupaten Buton Utara dalam formasi pengadaan PNS, namun belum optimal.
\end{abstract}

Kata kunci : Formasi, Pegawai Negeri Sipil (PNS), Buton Utara 


\begin{abstract}
Ideally in determining the formation of civil servants based on needs in terms of the type, nature and workload of each unit of government agency. The government's policy in determining the formation of civil servants is always based on budget considerations listed in the respective Regency/City APBD. This research was conducted to determine the analysis of formations in the Procurement of Civil Servants within the Scope of the Regional Government of North Buton Regency.This study uses a qualitative approach, with the focus of research on the formation of civil servants within the North Buton Regency Government. The informants in this study were 6 people consisting of 3 officials at the North Buton BKPSDM, 1 CPNS and 2 community leaders who were selected using purposive sampling technique. Data were collected by interview, observation and document study methods. The data collected was then analyzed descriptively, with the stages of data collection, data processing, data reduction and drawing conclusions. The data that has been analyzed is then triangulated to obtain an overview of the analysis of the formation of civil servants procurement in North Buton Regency.The results show that the formation analysis in the procurement of civil servants within the local government of North Buton Regency has not fully used the job map indicators, the number of employees who retire every year and the ratio of the population to civil servants. The three indicators are not analyzed in depth so that the formation of civil servants procurement is not in accordance with the real needs of existing positions in North Buton Regency. However, the North Buton Regency Government has provided a budget through the North Buton Regency APBD in the formation of civil servants procurement, but it has not been optimal.. Keywords: Formation, Civil Servants (PNS), North Buton.
\end{abstract}




\section{Pendahuluan}

Berdasarkan Peraturan Kepala Badan Kepegawaian Negara Nomor 19 Tahun 2011 tentang Pedoman Umum Penyusunan Kebutuhan Pegawai Negeri Sipil disebutkan bahwa formasi pegawai negeri sipil yang selanjutnya disebut formasi adalah jumlah dan susunan perangkat Pegawai Negeri Sipil yang diperlukan dalam suatu Satuan Organisasi Negara untuk mampu melaksanakan tugas pokok dalam jangka waktu tertentu. Penetapan formasi PNS memiliki tujuan agar satuan-satuan organisasi Negara mempunyai jumlah dan mutu pegawai yang memadai sesuai beban kerja dan tanggung jawab masing-masing satuan organisasi. Formasi ditetapkan berdasarkan analisis kebutuhan dalam jangka waktu tertentu dengan mempertimbangkan macam-macam pekerjaan, rutinitas pekerjaan, keahlian yang diperlukan untuk melaksanakan tugas dan hal-hal lain yang mempengaruhi jumlah dan sumber daya manusia yang diperlukan (Sekretariat Jenderal Bina Konstruksi, 2016).

Dalam penyusunan dan kebutuhan jumlah dan jenis Jabatan PNS dilakukan sesuai dengan siklus anggarannya, pelaksanaannya dilihat berdasarkan analisis Jabatan dan analisis beban kerja di setiap Instansi Pemerintah yang dilakukan dalam jangka waktu 5 (lima) tahun dan diperinci 1 (satu) tahun berdasarkan prioritas kebutuhannya. Dalam rangka penyusunan kebutuhan PNS akan mempertimbangkan beberapa hal seperti dinamika/perkembangan organisasi Kementerian/Lembaga guna mencapai tujuan Instansi Pemerintah. Jenis jabatan yang ada terdiri dari Jabatan Administrasi, Jabatan Fungsional dan Jabatan Pimpinan Tinggi. Rincian kebutuhan PNS pada setiap tahunnya disusun berdasarkan hasil analisis dari Jabatan dan hasil beban kerja itu sendiri. Kemudian hasil penyusunan kebutuhan PNS akan disampaikan oleh Pejabat Pembina Kepegawaian (PPK) dengan melampirkan beberapa dokumen rencana strategis Instansi Pemerintah, lalu untuk penetapan kebutuhan PNS tahun berikutnya akan di sampaikan oleh PPK Instansi Pemerintah kepada Menteri dan Kepala Badan Kepegawaian Negara (BKN) (Prasodjo, 2014). Formasi pegawai masing-masing OPD disusun berdasarkan kebutuhan dan penyediaan pegawai sesuai dengan 
jabatan yang tersedia dengan mempertimbangkan informasi jabatan (Rakhmawanto, 2018).

Kabupaten Buton Utara sebagai Daerah Otonom Baru (DOB) agar sejajar dengan kabupaten lain yang ada di Propinsi Sulawesi Tenggara memerlukan sumber daya manusia yang professional dan berkualitas, serta mampu mengahadapi tantangan dan perubahan organisasi. Sejak dimekarkan pada tahun 2007 Kabupaten Buton Utara baru 3 (tiga) kali menyelenggarakan proses rekrutmen CPNS, yaitu tahun 2014, 2018 dan 2019. Pada tahun 2014 berhasil direkrut sebanyak 121 orang (asncpns.com. 2015). Selanjutnya tahun 2018 sebanyak 275 formasi (Firdaus, 2018) dan yang terakhir tahun 2019 sebanyak 183 orang (Admin, 2019).

Berdasarkan BPS (2014) PNS di Kabupaten Buton Utara pada tahun 2015 berjumlah 2646 orang. Pada tahun 2015 jumlah pegawainya bertambah 3 orang menjadi 2.649 (BPS, 2016). Pada tahun 2016 jumlah pegawai di Kabupaten Buton Utara mengalami penurunan yang cukup drastis menjadi 2.275 orang (BPS, 2017), hingga pada tahun 2018 tersisa 2.126 orang (BPS, 2018). Menurut Hasan (2019) sebagaimana dikutip oleh Saban (2019) Berdasarkan analisis kebutuhan formasi pengadaan CPNS Kabupaten Buton Utara membutuhkan pegawai secara keseluruhan sebanyak 3.626 orang. Untuk memenuhi harapan tersebut pada tahun 2019 Pemerintah Kabupaten Buton Utara mengusulkan formasi CPNS sebanyak 1.500 orang. Namun karena terkendala dengan Anggaran Pendapatan dan Belanja Daerah (APBD) Kabupaten Buton Utara yang belum memadai sehingga formasi yang disetujui oleh Kementerian Pendayagunaan Aparatur Negara Reformasi dan Birokrasi hanya menyetujui 183 orang, terdiri dari tenaga pendidik 84 0rang, tenaga medis 76 orang dan tenaga teknis lainnya sebanyak 23 orang (Saban, 2019).

Menurut Rakhmawanto (2018) untuk menetapkan formasi Pegawai Negeri Sipil secara proporsional dan ideal, senantiasa didasarkan pada analisis kebutuhan dilihat dari jenis, sifat dan beban kerja pada setiap organisasi perangkat daerah. Kebijakan pemerintah dalam menentapkan formasi Pegawai Negeri Sipil harus mempertimbangkan ketersediaan belanja pegawai dalam APBD. Pada tahun 2019 besaran APBD Kabupaten Buton Utara mencapai Rp 661,484 Miliar. Dari sejumlah dana tersebut porsi untuk tidak belanja langsung sebesar 314.958 miliar 
untuk belanja pegawai, penyesuaian ADD dan belanja hibah untuk KPU dan Bawaslu/ sementara untuk belanja langsung mendapat porsi sebesar Rp. 358,800 miliar untuk urusan wajib, urusan pilihan pemerintah dan urusan fungsi penunjang (Islahudin, 2019). Hasil studi Citra dan Yunus menyebutkan kebutuhan dan pengadaan tentang pegawai dalam penempatan CPNS tidak sesuai kebutuhan yang ada di BKD. Rakhmawanto (2018) beberapa permasalahan terkait formasi pegawai antara lain terjadinya ketidakefektivan kinerja karena jabatan yang kurang jelas, jumlah dan komposisi PNS di setiap unit lembaga pemerintahan tidak merata, adanya ketidakseimbangan antara beban pekerjaan dengan jumlah PNS yang ditempatkan, analisis jabatan yang tidak dijadikan dasar dalam penghitungan kebutuhan PNS, penentuan formasi PNS dan penempatan PNS serta instansi pemerintah tidak secara rutin melakukan analisis kebutuhan PNS yang merespon dinamika dan tuntutan lingkungan strategis. Kondisi ini juga berpeluang terjadi di BKPSDM Kabupaten Buton Utara.

Berdasarkan hasil observasi dengan PNS lingkup Pemerintah Kabupaten Buton Utara terkait dengan formasi PNS Lingkup Pemerintah Kabupaten Buton Utara pada Badan Kepegawaian dan Pengembangan Sumber Daya Manusia Kabupaten Buton Utara belum sesuai dengan harapan masyarakat. Hal ini dapat dilihat dari beberapa indicator formasi pengadaan pegawai seperti perkiraan kapasitas pegawai, jenjang dan jumlah jabatan serta pangkat, analisis jabatan, peralatan yang tersedia dan kemampuan keuangan daerah yang belum memadai. Belum terwujudnya indicator formasi pengadaan pegawai sebagaimana dimaksud di atas berdampak pada distribusi pegawai yang tidak merata. Kecenderungan pegawai lebih dominan bertugas di sekitar kawasan perkotaan dan dalam kota, sehingga organisasi perangkat daerah di luar kota (perdesaan) memiliki pegawai yang lebih sedikit. Banyaknya jabatan eselon II, III dan IV belum berjalan dengan baik. Hal ini disebabkan oleh karena masih banyak jabatan yang masih kosong (belum terisi). Formasi jabatan PNS di Kabupaten Buton Utara pada tahun 2019 sebanyak 652 jabatan, terdiri dari eselon II.a 1 orang, eselon II.b 37 orang, eselon III.a sebanyak 51 orang, eselon III.b sebanyak 95 orang, eselon IV.a sebanyak 394 orang dan eselon IV.b sebanyak 74 orang. Namun dari seluruh jabatan yang ada 
hanya 540 jabatan yang terisi, sisanya 112 jabatan masih kosong (belum terisi). Jabatan yang belum terisi tersebut terdiri dari eselon II.a 1 orang, eselon II.b sebanyak 7 orang, eselon III.a 1 orang, eselon III.b sebanyak 2 orang, eselon IV.a sebanyak 68 orang dan eselon IV.b sebanyak 33 orang. Selain itu, peralatan yang tersedia dalam mendukung rekrutmen PNS bersifat during juga belum tersedia dengan baik, sehingga mengalami kendala terutama terkait dengan pertemuanpertemuan yang dilakukan secara virtual. Kendala lain dari aspek anggaran yang belum maksimal, sehingga sulit untuk mewujudkan pengadaan PNS yang berkualitas. Tujuan studi ini adalah untuk menganalisis formasi PNS Lingkup Pemerintah Kabupaten Buton Utara.

\section{Metode}

Penelitian ini mernggunakan pendekatan kualitatif, dengan fokus penelitian pada formasi PNS lingkup Pemerintah Kabupaten Buton Utara. Informan dalam penelitian ini berjumlah 6 orang yang terdiri atas 3 orang pejabat di BKPSDM Buton Utara, 1 orang CPNS dan 2 orang tokoh masyarakat yang dipilih dengan mengunakan teknik Purposive sampling. Data dikumpulkan dengan metode wawancara, observasi dan studi dokumen. Data yang dikumpulkan selanjutnya dianalisis secara deskriptif, dengan tahapan pengumpulan data, pengolahan data, reduksi data dan penarikan kesimpulan. Data yang telah dianalisis selanjutnya dilakukan triangulasi untuk memperoleh gambaran tentang analisis formasi pengadaan PNS di Kabupaten Buton Utara.

\section{Hasil dan Pembahasan}

\section{Pengadaan Formasi Pegawai di Kabupaten Buton Utara}

\section{a. Peta Jabatan}

Peta Jabatan adalah susunan jabatan yang digambarkan secara vertikal maupun horizontal menurut struktur kewenangan, tugas, dan tanggung jawab jabatan serta persyaratan jabatan. Tujuan dilakukan penyusunan peta jabatan adalah agar diproleh acuan pasti bahwa kebutuhan BKPSDM membutuhkan dukungan SDM dengan kualifikasi yang tepat sesuai tugas pokok dan fungsinya, serta 
mengetahui kondisi saat ini pegawai yang ada (bezetting) untuk selanjutnya merencanakan rekruitmen pegawai selanjutnya.

Peta jabatan menggambarkan seluruh jabatan yang ada dan kedudukannya dalam unit kerja. Sebagaimana diketahui bahwa di Kabupaten Buton Utara selama beberapa tahun terakhir selalu terlibat dalam perekrutan CPNS. Selain karena usia kabupaten yang relative muda, aspek lain yang menjadi pertimbangan utama adalah kondisi peta jabatan pada pemerintahan daerah Buton Utara yang masih memiliki lowongan kerja untuk mengisi struktur jabatan di Buton Utara. Berdasarkan hasil pemetaan pada tahun 2019 BKPSDM Kabupaten Buton Utara mengajukan kuota CPNS sebanyak 1500 orang pada Kemenpan RB tetapi realisasi yang diberikan hanya 183 orang. Jadi berdasarkan hal tersebut Pemerintah Kabupaten Buton Utara defisit banyak pegawai.

Hal ini menunjukkan bahwa Usulan formasi pengadaan CPNS di Buton telah dilakukan berdasarkan pertimbangan peta jabatan sebagai manifestasi dari analisis jabatan yang dilakukan oleh setiap institusi di Buton Utara. Hal ini disampaikan oleh kepala BKPSDM Buton Utara bahwa Dalam hal pengusulan formasi CPNS, secara khusus kami melakukan analisis jabatan pada instansi BKPSDM, selain itu juga kami meminta hasil analisis jabatan pada setiap OPD untuk memetakan postur PNS di Buton Utara. Perencanaan pengadaan pegawai negeri sipil di Kabupaten Buton Utara yang pertama dilakukan adalah menggunakan hasil analisis jabatan (ANJAB), hasil analisis beban kerja (ABK) serta pernyataan tentang kesiapan anggaran pemerintah daerah kabupaten Buton Utara. Analisis kebutuhan pegawai diperoleh melalui analisis jabatan untuk mengetahui dan mendapatkan secara konkrit jumlah dan kualifikasi pegawai yang dibutuhkan oleh suatu unit organisasi untuk mampu melaksanakan tugasnya secara berdaya guna, berhasil guna, dan berkesinambungan.

Dalam analisis jabatan kegiatan yang dilakukan berupa kegiatan mengumpulkan, menilai, dan mengorganisasikan informasi tentang jabatan. Analisis jabatan meliputi: (1). Uraian jabatan atau uraian pekerjaan, yaitu informasi yang lengkap mengenai tugas dan berbagai aspek lain dari suatu jabatan atau pekerjaan. (2). Kualifikasi atau syarat-syarat jabatan, yaitu keterangan tentang 
syaratsyarat yang diperlukan oleh seorang pegawai untuk dapat melakukan tugas tertentu misalnya pendidikan tertentu. (3). Peta jabatan, yaitu susunan nama dan tingkat jabatan struktural dan fungsional yang terlihat dalam suatu struktur unit organisasi dari tingkat yang paling rendah sampai dengan yang paling tinggi dan jenis jabatan fungsional serta jumlah yang diperlukan.

Analisis jabatan ABK saat ini yang terjadi selalu berubah setiap periode sesuai dengan struktur dalam setiap OPD, khususnya apabila terjadi penggabungan SKPD atau hal lainnya sehingga harus selalu berubah. Berkenaan dengan hal tersebut, dalam proses analisis jabatan, sebenarnya BKPSDM hanya melaksanakan kegiatan tersebut dalam kegiatan rekruitmen pegawai. Selanjutnya, hasil dari analisis jabatan yang telah direview oleh BKPSDM akan disandingkan dengan angka kondisi riil yang ada sehingga menghasilkan kelebihan atau kekurangan pegawai di daerah. BKPSDM akan mengajukan ke MENPAN mengenai kelebihan atau kekurangan pegawai melauli aplikasi e-formasi, dimana aplikasi tersebut berkaitan dengan penyusunan kebutuhan pegawai.

Peta jabatan merupakan output dari analisis jabatan yang dilakukan berdasarkan tugas pokok dan fungsi organisasi. Melalui analisi jabatan akan diperoleh informasi jabatan yang merujuk pada ikhtisar jabatan beserta uraian tugasnya sehingga dapat ditentukan beban kerja dari suatu jabatan tertentu. Rangkaian ini akan melahirkan jumlah kebutuhan personil dalam suatu jabatan tertentu. Dengan kata lain proses ini akan melahirkan jumlah kebutuhan pegawai yang akan diajukan melalui usulan formasi pada penerimaan CPNS. Berdasarkan hasil analisis jabatan yang dituangkan dalam peta jabatan untuk setiap instansi yang diberikan kuota pegawai berdasarkan usulan yang dilakukan oleh BKPSDM di Buton Utara sudah sesuai dengan kebutuhan prioritas yang diusulkan oleh setiap instasni. Artinya usulan formasi pengadaan CPNS di Buton Utara berdasarkan kriteria peta jabatan telah terpenuhi. Misalnya usulan formasi tenaga kesehatan tahun 2019 untuk tenaga dokter di puskesmas Waode Buri sesuai dengan dokumen hasil analisis jabatan dipuskesmas tersebut membutuhkan satu orang tenaga dokter

Namun demikian, berdasarkan asumsi peta jabatan tersebut juga masih menyisahkan masalah lainnya, yakni tidak terpenuhinya kuota usulan sesuai dengan 
hasil analisis formasi yang dilakukan oleh setiap OPD, misalnya formasi tenaga pendidikan sampai saat ini belum memenuhi kebutuhan sesuai dengan hasil peta jabatan. Hal ini mengandung makna bahwa analisis yang dilakukan oleh BKPSDM dalam menyusun usulan formasi CPNS tidak secara langsung menerima secara keseluruhan apa yang diusulkan oleh OPD melalui hasil analisis jabatan dan peta jabatan. Sebab penetapan jumlah formasi yang diterima ditentukan oleh pemerintah pusat. Konsekuensinya bahwa penerimaan yang dilakukan belum bisa memenuhi kebutuhan organisasi berdasarkan hasil analisis jabatan. Namun demikian, analisis jabatan dapat digunakan untuk menentukan formasi kebutuhan pegawai pada tahun berikutnya. Hal ini sejalan dengan Nangameka dan Baidhowah (2020) bahwa peta jabatan merupakan suatu keniscayaan untuk menjamin organisasi pemerintah telah memiliki jumlah jabatan, tugas pokok, serta struktur yang tepat dalam rangka menopang fungsi organisasi pemerintah tersebut. Peta jabatan juga dilakukan untuk mengetahui kebutuhan riil PNS (Rakhmawanto, 2016). Penyusunan formasi PNS di Kabupaten Buton Utara telah disusun sesuai peta jabatan yang tersedia pada masing-masing OPD.

\section{b. Jumlah Pegawai yang Pensiun}

Jumlah pegawai yang pensiun merupakan salah satu faktor yang menjadi pertimbangan bagi suatu daerah untuk melakukan penerimaan CPNS. Berdasarkan hasil penelitian, diperoleh keterangan bahwa jumlah pegawai yang pensiun di Buton Utara Setiap tahunnya selalu ada pegawai yang pensiun, namun jumlahnya variatif atau tidak menentu. Pada tahun 2018 jumlah pegawai yang pension sebanyak 14 orang dan pada tahu 2019 sebanyak 33 orang.

Berdasarkan jumlah pegawai pensiun, setiap instansi pemerintah di Kabupaten Buton Utara menyusun kebutuhan jumlah dan jenis jabatan PNS baru berdasarkan analisis jabatan dan analisis beban kerja. Penyusunan kebutuhan jumlah dan jenis jabatan PNS dilakukan untuk jangka waktu 5 (lima) tahun yang diperinci per 1 (satu) tahun berdasarkan prioritas kebutuhan. Penyusunan kebutuhan PNS, harus dapat mendukung pencapaian tujuan instansi. Penyusunan kebutuhan PNS juga dilakukan melalui analisis beban kerja pegawai yakni 
frekuensi rata-rata masing-masing jenis pekerjaan dalam jangka waktu tertentu. Perkiraan beban kerja dari masing-masing satuan organisasi dapat dilakukan sesuai dengan perhitungan atau berdasarkan pengalaman, misalnya perkiraan beban kerja pengetikan, pengagendaan, dan yang sejenis dengan itu dapat didasarkan atas jumlah surat yang masuk dan keluar rata-rata dalam jangka waktu tertentu. Apabila sudah dapat diperkirakan beban kerja masing-masing satuan organisasi, maka untuk dapat ditentukan jumlah pegawai yang diperlukan dengan memperhitungkan jumlah pegawai yang pensiun. Dalam analisis formasi yang kami lakukan telah mempertimbangkan jumlah pegawai yang pensiun dan pegawai yang memasuki masa pensiun, paling tidak dua tahun sebelum pensiun BKPSDM Kabupaten Buton Utara sudah menghitungnya.

Hasil observasi diketahui bahwa distribusi pegawai di Kabupaten Buton Utara berdasarkan usia menunjukkan bahwa pegawai yang masuk dalam kelompok usia lebih dari 50 tahun cukup tinggi yakni sebesar 23\%. Apabila merujuk pada Pasal 3 ayat 2 PP No. 32 Th 1979 tentang Pemberhentian Pegawai Negeri Sipil, yang diubah menjadi PP No. 65 tahun 2008 menjelaskan bahwa batas usia pensiun untuk kategori PNS umum adalah 56 tahun. Demikian dalam berapa tahun kedepan akan selalu ada pegawai di Buton Utara yang pensiun. hal in menunjukkan bahwa kegiatan penyusun formasi penerimaan pegawai di buton utara telah memenuhi unsur sesuai aspek jumlah pegawai yang pensiun. meskipun jumlah formasi yang diusulkan lebih besar dari pada jumlah pegawai yang pensiun setiap tehunnya tetapi potensi pegawai yang pensiun berdasarkan usia pegawai akan selalu ada setiap tahunnya selama beberapa tahun kedepan. Hal ini sejalan dengan Citra dan Yunus (2019) lowongan PNS pada organisasi pemerintah disebabkan oleh karena adanya PNS yang pensiun, meninggal dunia, mutasi jabatan, pengembangan organisasi dan sebagainya, sehingga kekosongan tersebut diisi melalui penambahan pegawai baik kuantitas, kualitas maupun kompetensi jabatan yang dibutuhkan.

\section{c. Rasio Jumlah PNS dan Jumlah Penduduk}

Untuk memberikan pelayanan masyarakat (public service) yang profesional, dibutuhkan perbandingan obyektif (rasional) antara jumlah Pegawai Negeri Sipil (PNS) dengan jumlah penduduk sebagai obyek pelayanan. 
Rasionalisasi PNS dengan jumlah penduduk guna menciptakan distribusi PNS dan pelayanan publik yang lebih proporsional. Komposisi penduduk Kabupaten Buton Utara sampai tahun 2018 didominasi oleh penduduk usia produktif 15-64 tahun. Pada tahun 2018 usia produktif 15-64 tahun sebanyak 53\% dari jumlah penduduk. Jumlah penduduk usia 0-14 tahun sebanyak 45\% sedangkan jumlah penduduk usia 65 tahun ke atas sebanyak 2\%. Dengan komposisi penduduk tersebut maka angka rasio ketergantungan (dependency rasio) sebesar 84,9 yang berarti bahwa setiap 100 penduduk produktif akan menanggung 85 penduduk usia non produktif.

Untuk dapat mengetahui seimbang atau tidaknya jumlah Pegawai Negeri Sipil (PNS) di suatu negara atau daerah dapat dilihat dari rasio idealnya, untuk Negara Indonesia sendiri rasio idealnya jumlah Pegawai Negeri Sipil (PNS) adalah 1,5 persen dari jumlah penduduk (Harahap, 2017). Pada wilayah Kabupaten Buton Utara, rasio ASN dengan jumlah penduduk juga mengalami penurunan sejak tiga tahun terakhir (2017-2019). Tahun 2019 jumlah PNS di Buton Utara sebesar 2333 orang dengan jumlah penduduk sebesar 66291 jadi diperkirakan rasionya adalah sebesar 3,52\%"

Berdasarkan pernyataan tersebut, kemudian peneliti melakukan penelusuran data Statistik Pegawai Negeri Sipil (PNS) lingkup pemerintah daerah Buton Utara ditemukan bahwa dari tahun 2017 sampai dengan tahun 2019 jumlah PNS terus mengalami perubahan yang fluktuatif yakni berturut-turut sebanyak 2307 orang, 2257 orang, dan 2333 orang. Disisi lain, dalam kurun waktu tersebut jumlah penduduk Buton Utara mengalami peningkatan yakni berturut turut sebanyak 62.088 jiwa, 63.066 jiwa, dan 66.291 jiwa (BPS 2017). Berdasarkan angka tersebut dapat diketahui bahwa rasio jumlah PNS dan Jumlah penduduk di Kabupaten Buton Utara selama kurun waktu tahun 2017-2019 selalu mengalami penurunan, dimana pada tahun 2017 rasionya 3,72 persen kemudian berkurang secara terus-menerus setiap tahunnya hingga pada tahun 2019 mencapai angka 3,52 persen.

Berdasarkan angka proporsi ideal secara nasional yang diproyeksi sebesar 1,5\% maka hal ini memperlihatkan bahwa jumlah ASN di Buton Utara sudah tidak ideal atau telah melebihi batas proporsi ideal untuk jumlah PNS. Jika dibandingkan dengan daerah-daerah lain di Sulawesi Tenggara, dapat diperoleh bahwa angkara 
Rasio Jumlah PNS dan jumlah pendudukan Buton Utara hanya lebih rendah dari Kabupaten Konawe Utara yang mencapai 3,99\% pada tahun 2018. Hal ini sejalan dengan yang dikemukakan oleh Rakhmawanto (2016) bahwa formasi pengadaan PNS harus mempertimbangkan rasio jumlah penduduk dan PNS. Kondisi di Kabupaten Buton Utara berdasarkan analisis data di atas menunjukkan bahwa formasi pengadaan PNS sudah tidak layak karena sudah melampaui rasio yang ditetapkan secara nasional. Kelebihan PNS menyebabkan beban anggaran karena gaji yang diterima dengan hasil pekerjaan tidak sebanding hasilnya (Rakhmawanto, 2016).

Namun demikian, adanya tren penurunan angka rasio jumlah PNS dan jumlah penduduk bahkan setelah Kabupaten Buton Utara terus melakukan penerimaan pegawai, maka apabila tidak dilakukan penerimaan pegawai maka hal tersebut berpotensi menjadikan Buton Utara kekurangan pegawai. Dengan demikian dapat dikatakan bahwa penerimaan pegawai yang dilakukan oleh kabuapaten Buton Utara saat ini masih dalam kondisi yang wajar. Bahkan Negara Malaysia memiliki Rasio PNS terhadap jumlah penduduk sebesar 3,7\% (Nugroho, 2016)

\section{d. Ketersediaan Anggaran}

Aspek penting yang harus diperhatikan dalam pengusulan formasi penerimaan CPNS adalah ketersedian Anggaran Belanja pegawai yang tidak menjadi beban berlebih bagi APBD sehingga pembangunan infrastruktur tidak berjalan. Secara umum gaji pegawai tentu saja masih tersedia. Bila merujuk dari data BPS 2020, persentase belanja pegawai kita tahun 2019 sebesar 27,5\% dari total APBD bahwa anggaran gaji pegawai masih memungkinkan bahkan untuk melakukan pengadaan CPNS di tahun berikutnya jika ada kuota dari Pusat.

Belanja pegawai merupakan belanja yang ditujukan untuk membiayai pelaksanaan kegiatan rutin suatu instansi pemerintah, sebagaimana ditentukan dalam tujuan pokok dan fungsinya. Kelompok belanja ini memiliki porsi terbesar dalam struktur belanja yang anggarannya bersumber dari APBN pada sebuah instansi/satuan kerja. Besar anggaran satu satuan kerja/instansi berbeda-beda dengan keragaman jenis belanja yang juga berbeda. Demikian halnya dengan 
kondisi yang terjadi di Kabupaten Buton Utara, bahwa berdasarkan hasil penelitian sebagaimana diungkapkan oleh kepala BKPSDM di atas bahwa belanja pegawai yang diporsikan dalam APBD masih menjamin terlaksananya pembangunan infrastruktur di wilayah Kabupaten Buton Utara melalui APBD.

Dalam konteks penegelolan anggaran maka rencana pengusulan formasi penerimaan CPNS di Kabupaten Buton Utara masih memperhatikan keseimbangan pemanfaatan belanja yang dapat dialokasikan untuk hal-hal produktif lainnya, misalnya untuk melakukan aktivitas pembangunan. Hal ini sejalan dengan hasil penelitian yang dilakukan oleh Darwis (2015) yang menyimpulkan bahwa belanja pegawai berpengaruh dan signifikan negatif terhadap tingkat kemandirian keuangan daerah pada tahun 2009-2013. Oleh karena itu, hendaknya Pemerintah daerah memproporsikan lebih besar belanja modal, agar terciptanya peningkatan infrastruktur yang akan meningkatkan laju pertumbuhan ekonomi daerah yang pada akhirnya akan meningkatkan potensi PAD dari berbagi sektor perekonomian sehingga PAD semakin meningkat dari tahun ke tahun.

Penganggaran biaya yang efektif dan efisien menjadi kunci keberhasilan pembangunan di daerah. Apabila persentase belanja pegawai tidak langsung ratarata sebesar 50\% yang digunakan untuk membiayai gaji pegawai maka dapat berdampak pada pencapaian keberhasilan pembangunan, dikarenakan belanja pegawai sebagai anggaran belanja terbesar yang menyerap dana APBD, dimana idealnya belanja modal seharusnya lebih besar dari belanja pegawai karena belanja modal secara langsung digunakan untuk kepentingan publik. Sebagaimana disampaikan oleh Mardiasmo (2005) yang menyebutkan alasan pentingnya anggaran sector publik bahwa anggaran merupakan alat bagi pemerintah untuk mengarahkan pembangunan sosial ekonomi, menjamin kesinambungan, dan meningkatkan kualitas hidup masyarakat.

Mekanisme penyusunan usulan Formasi pengadaan PNS yang dilakukan di Kabupaten Buton Utara saat dipandang sebagai hal positif serta mendukung kegiatan penataan pegawai sehingga postur pegawai pada setiap organisasi dapat memenuhi beban kerja yang proporsional. Artinya, dengan sistem yang berlaku saat ini dalam hal penyusunan Formasi, sebagaimana telah berjalan pada pengadaan 
PNS tahun 2014 sampai tahun 2019 maka kapasitas pegawai yang direkrut menyangkut kuantitas maupun kualitasnya memiliki peluang yang besar untuk dapat memenuhi harapan pemerintah.

\section{Kesimpulan}

Hasil penelitian menunjukkan formasi Pengadaan PNS Lingkup Pemda Kabupaten Buton Utara belum sepenuhnya menggunakan indikator peta jabatan, jumlah pegawai yang pensiun setiap tahun dan rasio jumlah penduduk dengan PNS. Ketiga indikator tersebut tidak dilakukan analisis secara mendalam sehingga formasi pengadaan PNS tidak sesuai dengan kebutuhan rill jabatan yang ada di Kabupaten Buton Utara. Namun demikian Pemerintah Kabupaten Buton Utara telah menyediakan anggaran melalui APBD Kabupaten Buton Utara dalam formasi pengadaan PNS, namun belum optimal. Diharapkan kepada BKPSDM Kabupaten Buton Utara agar dalam pengadaan formasi PNS agar melakukan analisis berdasarkan indikator peta jabatan dengan mempertimbangkan kebutuhan rasio PNS dengan jumlah penduduk yang ada.

\section{Referensi}

Admin. (2019). Pendaftaran CPNS Kabupaten Buton Utara 2019. https://www.caradaftarcpns.com/pendaftaran-cpns-kabupaten-butonutara-2019

BPS. (2016). Kabupaten Buton Utara dalam Angka 2016. BPS Kab. Buton Utara. BPS. (2017). Kabupaten Buton Utara dalam Angka 2017. BPS Kab. Buton Utara BPS. (2018). Kabupaten Buton Utara dalam Angka 2018. BPS Kab. Buton Utara. Citra, Auliya dan Yunus, Muh. (2019). Formasi Kebutuhan Pegawai Dalam Penerimaan Calon Pegawai Negeri Sipil (CPNS) Badan Kepegawaian Daerah Kota Makassar Al-Din (Jurnal Dakwah dan Sosial Keagamaan). Volume (5), Nomor (2). Hal : 1-12.

Darwis, Tria E., (2015). Pengaruh Belanja Modal Dan Belanja Pegawai Terhadap Tingkat Kemandirian Keuangan Daerah Pada Kabupaten/Kota Provinsi 
Sumatera Barat (Studi Empiris Pada Kabupaten dan Kota Provinsi

Sumatera Barat). Jurnal Akuntasi. Volume (3), Nomor (1).

Firdaus, Fitra. (2018). CPNS 2018: Kabupaten Buton Utara Buka 275

Formasi.Tirto.id. https://tirto.id/cpns-2018-kabupaten-buton-utarabuka-275-formasi-c1DD

Mardiasmo. (2005). Akuntansi Sektor Publik. Yogyakarta : Penerbit Andi.

Nangameka, Teresa dan Baidhowah, R. Adfin. (2020). Manajemen Kepegawaian

Di Kementerian Dalam Negeri: Isu-Isu Yang Dihadapi. Jurnal MSDA

(Manajemen Sumber Daya Aparatur) Vol 8, No. 2, 2020, pp. 133-157.

Nugroho, Riant. (2016). Rasionalisasi PNS dan 3 Kesalahan Menteri PAN-RB.

https://www.cnnindonesia.com/ekonomi/20160607170031-79-

136476/rasionalisasi-pns-dan-3-kesalahan-menteri-pan-rb

Peraturan Pemerintah No. 65 tahun 2008 tentang Perubahan Kedua Atas Peraturan

Pemerintah Nomor 32 Tahun 1979 Tentang Pemberhentian Pegawai Negeri Sipil

Prasodjo Eko. (2014). “Undang-undang Aparatur Sipil Negara: Membangun

Profesionalisme Aparatur Negara". Jurnal Kebijakan dan Manajemen PNS Vol. 8 No. 1 Juni. 2014.

Rakhmawanto, Ajib. (2016). Rasionalisasi Kebutuhan Dan Distribusi Pns Nasional.

Civil Apparatus Policy Brief. Nomor 002. Jakarta : Badan Kepegawain Negara.

Rakhmawanto, Ajib. (2018). Perspektif Pemberian Formasi Pegawai Negeri Sipil Berdasarkan Anggaran Pemerintah Daerah: Perspective For Giving Civil Servants Formation Based On The Regional Government Budget. e-Journal BKN. Volume (12) Nomor (2), hal : 91-104. https://jurnal.bkn.go.id/index.php/asn/article/view/27

Sekretariat Dirjen Bina Konstruksi. (2016). Formasi Pegawai Prioritas Diterapkan Ditjen Bina Konstruksi. Jakarta : Kementerian Pekerjaan Umum Direktorat Jenderal Bina Konstruksi. https://binakonstruksi.pu.go.id/informasi-terkini/sekretariat-direktoratjenderal/formasi-pegawai-prioritas-diterapkan-ditjen-bina-konstruksi/ 
Saban, Adrian. (2019). 12 Tahun Butur Mekar, Baru Pelamar CPNS 2019 yang Terbanyak. Sultrakini.com. https://sultrakini.com/12-tahun-buturmekar-baru-pelamar-cpns-2019-yang-terbanyak/ 